\title{
ANALISA PERUBAHAN FASE PADA SISTEM PENGKONDISIAN UDARA RUANGAN TYPE SPLIT 1 PK
}

\author{
${ }^{(1)}$ Maulana Lathif, ${ }^{(2)}$ Gusti Rusydi Furqon Syahrillah, ${ }^{(3)}$ Saifullah Arif \\ ${ }^{(1)(2)(3)}$ Prodi Teknik Mesin Fakultas Teknik, Universitas Islam Kalimantan MAB \\ JI. Adhiyaksa No. 2 Kayu Tangi, Banjarmasin \\ Email: latifmaulana157@gmail.com,rani_rusdi@yahoo.com, \\ saifullahariefs2@gmail.com
}

\begin{abstract}
ABSTRAK
Pendingin ruang yang menggunakan sistem kompresi uap dengan menggunakan alat penukar kalor sehingga terjadi perubahan panas dan tekanan yang berada pada tekanan rendah dan tekanan tinggi yang stabil, dalam sistem ini menggunakan bahan pendingin (refrigerant) yang bersirkulasi menyerap panas dan melepas panas, serta terjadi perubahan dari tekanan rendah ke tekanan tinggi. Sirkulasi tersebut berulang secara terus-menerus dan jumlah refrigerant yang digunakan tetap dan hanya bentuk dari refrigerant saja yang berubah. Subjek penelitian ini adalah mesin pendingin jenis splite dengan kapasitas 1 PK yang banyak di gunakan di gedung kecil atau ruangan. Sedangkan untuk objek penelitian ini terdapat pada system pendingin air conditioner (AC) yang mempunyai karakteristik yang unik, panas dari engine serta kondisi-kondisi lainnya yang mempengaruhi design dan masalah pada sistem air conditioner (AC). Dari hasil penelitian dapat disimpulkan bahwa semakin tinggi putaran kompresor maka COP akan menurun, meningkatnya putaran kompresor menyebabkan temperature dan tekanan refrigerant yang keluar kompresor akan semakin meningkat, sehingga kerja kompresi yang dilakukan juga semakin besar. Hal ini berkebalikan dengan temperatur dan tekanan refrigerant yang masuk ke evaporator. Temperature dan tekanan refrigerant yang masuk evaporator akan semakin rendah dengan meningkat putaran kompresor, hal ini menyebabkan efek refrigrasi yang dihasilkan semakin rendah.
\end{abstract}

Kata Kunci : Pengkondisian udara, kompresor, evaporator

\section{PENDAHULUAN}

Sistem perubahan fase yang terjadi dalam pengkondisian merupakan penerapan bidang ilmu Termodinamika yang mempelajari tentang energi dan berbagai pemanfaatannya (terutama energi panas) dan proses tranformasinya. Peubahan fase terjadi dalam fluida kerja sistem pendingin yaitu pada refrigerant. Pada hakikatnya termodinamika sangat berperan penting dalam proses pengkondisian udara yang dianut oleh sistem pendingin pada air conditioner (AC). Maka dari itu pada kesempatan ini penulis akan membahas tentang analisa perubahan fase dari refrigent dalam ilmu termodinamika pada bagian mesin pendingin. Clausius menyatakan bahwa "tidaklah mungkin memindahkan kalor pada suhu rendah ke tandon bersuhu tinggi tanpa dilakuan usaha perumusan clausius sehubung dengan refrigerasi (mesin pendingin) yaitu untuk memindah kalor dari dalam refrigerasi yang bersuhu rendah keluar refrigerasi yang bersuhu tinggi. 


\section{METODE PENELITIAN}

- Tempat Penelitian

Penelitian ini bertempat di Salim AC Jalan Pemajatan km 1

- Waktu Penelitian

Waktu penelitian ini dilaksanakan sejak bulan Februari sampai dengan Maret 2018.

- Alat dan Bahan

1. Refrigeran

2. 1 Unit AC Splite $1 \mathrm{PK}$

3. Pressure gauge low and high pressure

4. Termometer

- Teknik Pengambilan Data

Data dikumpulkan dari hasil pengukuran langsung data yang dikumpulkan sewaktu pengujian berupa data temperatur evaporator dan kondensor dan data tekanan pada evaporator dan kondensor.

- Teknik Pengolahan Data

Data yang sudah dikumpulkan, kemudian diolah dalam bentuk tabel dan grafik tujuannya untuk mempermudah proses analisa.

\section{HASIL PEMBAHASAN}

Analisa Data

Setelah pengolahan data selanjutnya data di analisa, meliputi berapa besar nilai COP nya melalui $\mathrm{P}=$ $\mathrm{h}$ diagram

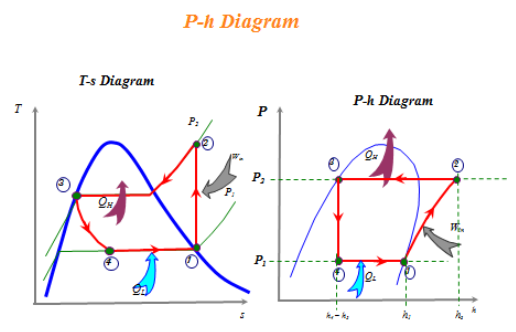

Gambar 3.7 Siklus kompresi uap

Melalui siklus akan di dapat data hasil pengukuran dan perhitungan hasil analisa pada setiap tahap. Nilai entalpy dan entropi akan di dapat melalui tabel sifat-sifat fluida sesuai dengan jenis refrigent yang di gunakan. Secara diagram dapat di lihat perubahan dari berbagai fase yang terjadi pada diagram di bawah ini

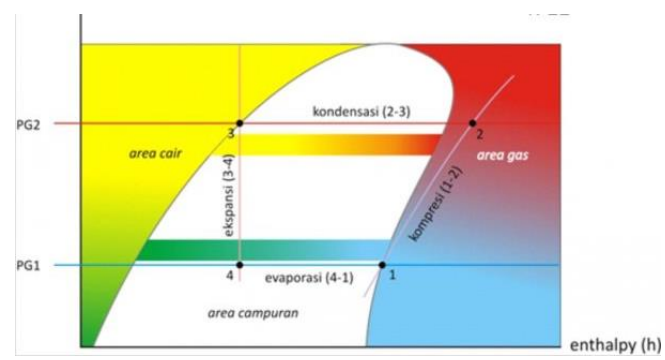

Gambar 3.8 Siklus perubahan fase

COP Carnot dapat dihitung dengan persamaan dimana:

$\mathrm{TL}=$ Temperatur refrigeran saat menyerap kalor (temperatur evaporator) $15^{\circ} \mathrm{C}$

$\mathrm{TH}=$ Temperatur refrigeran saat melepas kalor (temperatur kondensor) 40 ${ }^{\circ} \mathrm{C}$

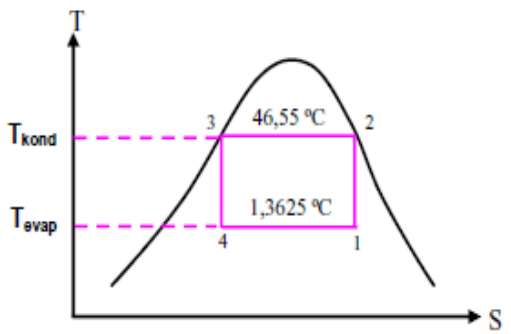

Gambar 4.3. Diagram T-S siklus Carnot

Maka:

COP Carnot

$=\frac{15+273}{(40+273)-(15+273)}$

Maka diperoleh COP carnot sebesar 11,52

COP Standar dapat dihitung dengan persamaan Dimana:

$\mathrm{Q}_{\text {evaporator }}=$ Kalor dari lingkungan yang diserap evaporator $(\mathrm{kW})$

$\mathrm{W}_{\text {kompresor }}=$ Kerja isentropik kompresor $(\mathrm{kW})$ 


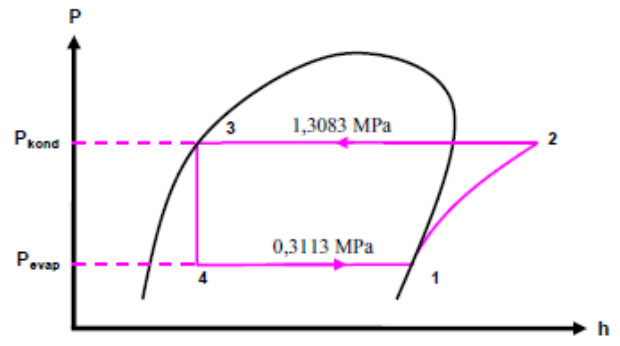

Gambar 4.4. Diagram p-h siklus ideal

Besarnya koefisien yang menyatakan performance dalam ideal pada siklus kompresi dapat dihitung dengan persamaan

(Refrigrasi dan Pengkondisian Udara. W.F. Stoeckr \& J.W. Jones, 1996)

Diketahui :

$$
C O P_{\text {ideal }}=273,15+\frac{T_{e}}{T_{c}-T_{e}}
$$

$$
\begin{gathered}
T_{e}=20+9=29^{\circ} \mathrm{C} \\
T_{c}=28+46=74^{\circ} \mathrm{C}
\end{gathered}
$$

Absolute temperature $(273,15)$

$$
\begin{aligned}
\text { COP }_{\text {ideal }} & =273,15+\frac{T_{e}}{T_{c}-T_{e}} \\
& =273,15+\frac{29}{74-29} \\
& =6,71
\end{aligned}
$$

\section{KESIMPULAN}

Berdasarkan penelitian yang sudah dilakukan dapat disimpulkan bahwa :

Untuk kerja Air Conditioning 1 PK yang dilihat dari nilai COP ideal dan COP standar sebesar 11,52 dan 11,2. Hal ini menunjukan sistem Air Conditioning tersebut bekerja dengan baik. Nilai COP standar lebih rendah Dibandingkan dengan nillai COP ideal hal ini dikernakan COP ideal tidak melibatkan kerugian.

\section{REFERENSI}

[1] CF Design Operational and Comunication sistem, Blue Ridge Numerics, Inc. 2008.

[2] BPPT Jakarta. Sistem Pengkondisian Udara Central, 2008
[3] Refrigerasi dan Pengkondisian Udara, Wibert F. Stoecker, Jerold W. Jones

[4] Schweizer-Ries, P., Fitriana, I., The BANPRES-LTSMD-Programme, Report on the Questionaire,

[5] ISE - Fraunhofer, 1998 